\title{
Nutritional metabolism of hydrogen peroxide/ anhydrous ammonia-treated barley straw in ewe lambs
}

\author{
Mohammed Diouri*, Randall D. WIEDMEIER \\ Skaggs Nutrition Research Laboratory, USU, Logan, UT 84322-4815, USA
}

(Received 28 July 1999; accepted 16 April 2000)

\begin{abstract}
A control and three treatments of barley straw were compared: $\mathrm{NH}_{3}(3 \%$ of dry matter (DM)), $3 \% \mathrm{NH}_{3}$ after rehydration of the straw to $15 \%$ moisture with water, and $3 \% \mathrm{NH}_{3}$ after rehydration to $15 \%$ moisture with a $\mathrm{H}_{2} \mathrm{O}_{2}$ solution $(0.32 \%$ of DM). Forages were fed to fistulated ewe lambs, with a supplement, at two levels of intake (ad libitum and 75\% ad libitum). At the ad libitum intake, the treatments mainly improved the intake; and digestible DM intake was 336, 455, 501, and 552 grams per head per day for untreated, $\mathrm{NH}_{3}, \mathrm{NH}_{3}+\mathrm{H}_{2} \mathrm{O}$, and $\mathrm{NH}_{3}+\mathrm{H}_{2} \mathrm{O}_{2}$-treated straws, respectively. The first, second, and fourth values were different from each other $(P<0.01)$, but the third one was not different from the fourth $(P=0.09)$. A similar trend was observed in most other nutrient utilization parameters and fermentation characteristics. Intake restriction raised DM digestibility from $56.9 \%$ to $58.2 \%(P=0.04)$. Anhydrous ammonia cannot provide alkalinity for the optimal action of hydrogen peroxide.
\end{abstract}

straw / treatment / ammonia / hydrogen peroxide

Résumé - Métabolisme alimentaire de la paille d'orge traitée à l'ammoniac anhydre et/ou à l'eau oxygénée chez les agnelles. Un témoin et trois traitements de paille d'orge : $\mathrm{NH}_{3}(3 \% \mathrm{MS})$, $3 \% \mathrm{NH}_{3}$ après réhydratation de la paille à $15 \%$ d'humidité avec de l'eau, et $3 \% \mathrm{NH}_{3}$ après réhydratation à $15 \%$ d'humidité avec une solution de $\mathrm{H}_{2} \mathrm{O}_{2}(0,32 \% \mathrm{MS})$ ont été comparés. Ces pailles ont été distribuées, à 8 agnelles fistulées, à deux niveaux d'ingestion (ad libitum et $75 \%$ ad libitum), selon un dispositif en carré latin. Lorsque l'ingestion était à volonté, les traitements ont agi principalement sur l'ingestibilité, et la MS digestible a été de 336, 455, 501, et 552 grammes par tête par jour pour le témoin, les pailles traitées à $\mathrm{NH}_{3}, \mathrm{NH}_{3}+\mathrm{H}_{2} \mathrm{O}$, et $\mathrm{NH}_{3}+\mathrm{H}_{2} \mathrm{O}_{2}$ respectivement. Les première, deuxième, et quatrième valeurs ont été significativement différentes l'une de l'autre $(P<0,01)$; alors que la troisième ne l'a pas été de la quatrième $(P=0,09)$. Une tendance semblable a été observée pour la plupart des autres paramètres de digestion. La digestibilité de la MS est passée, en moyenne, de 56,9\% à 58,2\% avec la restriction de l'ingestion $(P=0,04)$. L'ammoniac ne peut pas fournir une alcalinité suffisante pour une action optimale de l'eau oxygénée.

paille / traitement / ammoniac / eau oxygénée

* Correspondence and reprints

Université Moulay Ismaïl, Faculté des sciences, Département de Biologie, BP 4010, Béni M'hamed Meknès, Morocco.

Tel.: 21255388 70; fax: 21255368 08; e-mail: diouri @ fsmek.ac.ma 


\section{INTRODUCTION}

Anhydrous ammonia $\left(\mathrm{NH}_{3}\right)$ treatment of cereal straws has proven to be successful for several reasons. Its alkalinity makes cellulose and hemicellulose more available by partially dissolving them and by breaking the bonds between them and lignin. $\mathrm{NH}_{3}$ also supplements the straw with nitrogen, although only part of this added nitrogen is available to the animal [12].

Hydrogen peroxide $\left(\mathrm{H}_{2} \mathrm{O}_{2}\right)$ is another chemical compound that has greatly improved the utilization of different lowquality forages. This oxidizing agent acts optimally in alkaline medium [4].

Sodium hydroxide $(\mathrm{NaOH})$ has been used to provide alkalinity for $\mathrm{H}_{2} \mathrm{O}_{2}$ [7], but $\mathrm{NaOH}$ has the potential of sodium toxicity. Replacing it by $\mathrm{NH}_{3}$ was expected not only to remedy this disadvantage but also to enhance the beneficial effects of $\mathrm{NH}_{3}$. The main objective of this study was to determine the impact of the combined $\mathrm{NH}_{3} / \mathrm{H}_{2} \mathrm{O}_{2}$ treatment on straw nutritive value and the possible interaction or additivity of the two treatment components.

\section{MATERIALS AND METHODS}

\subsection{Treatments and animals}

Four different treatments were compared:

(1) Control, (2) $3 \% \mathrm{NH}_{3}$, (3) $3 \% \mathrm{NH}_{3}$ after rehydration of straw to $15 \%$ moisture with water, (4) $3 \% \mathrm{NH}_{3}$ after rehydration of straw to $15 \%$ moisture with a $\mathrm{H}_{2} \mathrm{O}_{2}$ solution (to reach a level of $0.32 \% \mathrm{DM}$ of $\mathrm{H}_{2} \mathrm{O}_{2}$ ).

Treatment 3 was used to isolate the effect of $\mathrm{H}_{2} \mathrm{O}_{2}$ and to confirm the results of former studies reporting the positive effect of moisture on straw ammoniation [8].

Ten $23 \mathrm{~kg}$ straw bales were randomly assigned to each of the four treatments. Ten bales were treated with enough water to bring the moisture level to $15 \%$. Ten bales were treated with a $\mathrm{H}_{2} \mathrm{O}_{2}$ solution to rehydrate to $15 \%$ moisture. All four stacks were then placed in separately sealed $6 \mathrm{~mm}$ plastic bags. $\mathrm{NH}_{3}$ was then introduced in the gaseous form into the appropriate bags through a perforated pipe at $3 \% \mathrm{DM}$. After ammoniation, the bags were sealed for approximately 21 days (during a moderately cold autumn) and then opened to allow excess ammonia to escape. Straw was then ground and mixed.

Eight yearling ewe lambs (30 to $51 \mathrm{~kg}$ ), fitted with ruminal fistulae, were used. The ewes were from three different breeds (4 Navajos, 2 Columbias, and 2 Blackfaced).

After proper recovery from fistulation and adaptation to a straw-based diet, sheep were placed in elevated metabolism crates.

Treatments were administered in a split plot with a $4 * 4$ Latin square design with repeated measures. Each of the 4 trial periods was composed of two subperiods. In the first subperiod, sheep had ad libitum access to straw in order to determine the intake. A supplement (whose nutrient composition is presented in Tab. I), composed of ground faba bean (Vicia faba) and fortified with vitamins and minerals as needed to meet nutrient requirements [13], was top dressed. The supplement intake was gradually adjusted to represent $25 \%$ of the ration in order to eliminate the possible negative associative effect between concentrate and roughage. Daily rations were given in 2 equal portions at 08.00 and $16.00 \mathrm{~h}$. Diets were fed for a $14 \mathrm{~d}$ adaptation period followed by a $7 \mathrm{~d}$ collection period.

In the second subperiod, consisting of $5 \mathrm{~d}$ adaptation and $5 \mathrm{~d}$ collection periods, the sheep received the same diet but their ration was limited to $75 \%$ of each animal's ad libitum intake.

\subsection{Measurements and analyses}

During $\mathrm{d} 1$ to 5 of the collection periods, total fecal output was collected and weighed 
Table I. Chemical composition of different treated straws and of the faba bean supplement (at the time of feeding).

\begin{tabular}{lccccc}
\hline Nutrients & Control & $\mathrm{NH}_{3}$ & $\mathrm{NH}_{3}+\mathrm{H}_{2} \mathrm{O}$ & $\mathrm{NH}_{3}+\mathrm{H}_{2} \mathrm{O}_{2}$ & Suppl. \\
\hline $\mathrm{DM}$ & 93.2 & 92.7 & 92.3 & 92.1 & 90.3 \\
\hline \multicolumn{5}{c}{$\%$ DM basis } \\
$\mathrm{nM}$ & 92.4 & 92.1 & 92.5 & 92.3 & 96 \\
$\mathrm{CP}$ & 3 & 7.2 & 7.8 & 8.1 & 21.1 \\
Cellulose $^{1}$ & 45.6 & 45.9 & 46.3 & 45.9 & 11.2 \\
Hemicellulose $^{2}$ & 27.8 & 24.9 & 23.4 & 23.5 & 19 \\
Lignin $^{2}$ & 8.4 & 7.7 & 7.6 & 7.2 & 2.2 \\
\hline
\end{tabular}

${ }^{1}$ ADF-ADL.

${ }^{2}$ NDF-ADF.

twice daily at the normal feeding times. Fecal samples were dried at $60{ }^{\circ} \mathrm{C}$ for $72 \mathrm{~h}$ and then ground and passed through a $2 \mathrm{~mm}$ screen. Composites of fecal samples, within ewe and period, were then made.

Feed (straw and supplement) and refusal were weighed at each feeding. Starting $1 \mathrm{~d}$ before the beginning of the collection periods, samples of feed and refusals were taken at each feeding. These samples were ground and passed through a $1 \mathrm{~mm}$ screen and proportional composites were made.

All feed, ort, and fecal composite samples were analyzed for laboratory dry matter (DM) $\left(105^{\circ} \mathrm{C}\right.$ for $\left.8 \mathrm{~h}\right)$, OM [1], CP [5], ADF, NDF, and ADL [14].

Rumen fluid samples were taken on days 6 and 7 of the ad libitum collection periods at $0,2,4,6,8,12$, and $16 \mathrm{~h}$ after the $16.00 \mathrm{~h}$ feeding of day 6 . Volatile fatty acids (VFA), ammonia nitrogen $\left(\mathrm{NH}_{3}-\mathrm{N}\right)$, and $\mathrm{pH}$ were measured. $\mathrm{pH}$ was taken immediately. Ammonia nitrogen was determined spectrophotometrically using Nessler's reagent [5]. Volatile fatty acids were determined by gas chromatography.

Data were analyzed using a general linear model including period, straw treatment, and sheep. Subperiod was later included in the model to test the intake level effect. The least significant difference (LSD) multiple mean comparison was applied to the variables studied.

\section{RESULTS AND DISCUSSION}

The nutrient composition of the four straws and of the supplement is presented in Table I. Crude protein was drastically increased by ammoniation, agreeing with Chestnut et al. [2]. The alkaline attack of ammonia on the ester bonds, linking lignin with cellulose and hemicellulose, supplied the straw with nitrogen. This alkaline attack also affected lignin and hemicellulose by partially dissolving them. The positive effects of ammoniation were further increased by rehydration of the straw. This was probably due to the phenomenon of fiber swelling [3], making the fibers more available to $\mathrm{NH}_{3}$. The presence of water increases the homogeneity of the reaction and provides an aqueous solution required by most chemical reactions. Another positive effect, (namely a decrease in forage lignin content) was added by $\mathrm{H}_{2} \mathrm{O}_{2}$ treatment probably because of the oxidizing ability of this component.

Cellulose content was not affected by the treatments. Nevertheless, digestible cellulose intake was increased by each additional treatment component. This may mean that 
cellulose became more available to the rumen microorganisms.

Since many animals could not stand the limited intake and did not go through the second subperiod, only the ad libitum intake values were used for treatment comparison.

At the ad libitum intake, digestible DMI was increased by ammoniation $(P=0.0006)$, by rehydration $(P=0.12)$, and by $\mathrm{H}_{2} \mathrm{O}_{2}$ $(P=0.09)$. Comparing $\mathrm{NH}_{3}$ with $\mathrm{NH}_{3}+$ $\mathrm{H}_{2} \mathrm{O}_{2}$ reveals a highly significant difference $(P=0.003)$. These three treatment components had similar effects on most nutrient utilization parameters (Table II). Although the DM digestibility was slightly increased, the improvement of digestible DMI was primarily obtained by an increase of the DMI. This increase in DMI was reported to be due to an increase in the rate and extent of fiber digestion [2]. The fermentation characteristics (Tab. II) were not improved enough (especially among the three treated straws) to allow a large increase in DM digestibility. The same pattern of influence of ammoniation was reported by LlamasLamas and Combs [10]. These authors obtained, however, a slightly higher improvement in DM digestibility than we did. This may be because they used wheat straw, which is more responsive to ammoniation than barley straw [6].

Rumen ammonia nitrogen and total VFA (Tab. II) confirmed the effect of ammoniation and that of rehydration. Propionate concentration was not affected by any of the treatment components. This disagrees with Males and Gaskins [11], who noted a higher propionate concentration when ammoniated straw was fed.

The trend of the response of DM digestibility (Tab. III) and of other digestion variables (data not shown) to the treatments was similar at limited intake.

Overall, limiting the intake enhanced DM digestibility $(P=0.04)$ and digestibility of other nutrients. This improvement was, however, minute. Similar findings have been reported by Llamas-Lamas and Combs [10].

In our study, as well as in many others [9], forage was ammoniated for 21 days. Since ambient temperature was low, this treatment time should have been lengthened in order to get better results for ammoniation.

Table II. Effect of straw treatments on nutrient utilization and fermentation characteristics at the ad libitum intake level.

\begin{tabular}{|c|c|c|c|c|c|}
\hline Item $^{1}$ & Control & $\mathrm{NH}_{3}$ & $\mathrm{NH}_{3}+\mathrm{H}_{2} \mathrm{O}$ & $\mathrm{NH}_{3}+\mathrm{H}_{2} \mathrm{O}_{2}$ & $\mathrm{SE}^{2}$ \\
\hline DMI $\left(\mathrm{g} \cdot\right.$ head $\left.^{-1} \cdot \mathrm{d}^{-1}\right)$ & $630^{\mathrm{b}}$ & $811^{\mathrm{c}}$ & $869^{\mathrm{cd}}$ & $936^{\mathrm{d}}$ & 32.2 \\
\hline DM digestibility (\%) & $53.7^{\mathrm{b}}$ & $56.3^{\mathrm{c}}$ & $57.9^{\mathrm{cd}}$ & $58.9^{d}$ & 0.64 \\
\hline Digestible DMI $\left(\mathrm{g} \cdot \mathrm{head}^{-1} \cdot \mathrm{d}^{-1}\right)$ & $337^{b}$ & $455^{\mathrm{c}}$ & $501^{\mathrm{cd}}$ & $552^{d}$ & 21.3 \\
\hline CP digestibility $(\%)$ & $57.8^{b}$ & $58.5^{\mathrm{b}}$ & $59.0^{\mathrm{b}}$ & $61.2^{\mathrm{b}}$ & 1.84 \\
\hline Cellulose digestibility (\%) & $57.4^{\mathrm{b}}$ & $61.5^{\mathrm{c}}$ & $61.8^{c}$ & $62.9^{c}$ & 1.2 \\
\hline Hemicellulose digestibility (\%) & $52.0^{\mathrm{b}}$ & $63.7^{\mathrm{c}}$ & $70.1^{\mathrm{d}}$ & $72.8^{d}$ & 1.53 \\
\hline $\mathrm{pH}$ & $6.82^{b}$ & $6.85^{\mathrm{b}}$ & $6.84^{b}$ & $6.81^{\mathrm{b}}$ & 0.04 \\
\hline $\mathrm{NH}_{3}-\mathrm{N}\left(\mathrm{mg} \cdot \mathrm{dl}^{-1}\right)$ & $13.4^{\mathrm{b}}$ & $19.8^{\mathrm{c}}$ & $21.8^{\mathrm{d}}$ & $19.9^{\mathrm{c}}$ & 0.6 \\
\hline Total VFA (mM) & $57.7^{b}$ & $65^{c}$ & $74.6^{\mathrm{d}}$ & $71.5^{\mathrm{cd}}$ & 2.5 \\
\hline Ac $\left(\mathrm{mol} \cdot 100 \mathrm{~mol}^{-1}\right)$ & $71.1^{\mathrm{b}}$ & $73.7^{\mathrm{c}}$ & $72.9^{c}$ & $72.9^{\mathrm{c}}$ & 0.5 \\
\hline $\operatorname{Pr}\left(\mathrm{mol} \cdot 100 \mathrm{~mol}^{-1}\right)$ & $17.5^{\mathrm{b}}$ & $16.7^{\mathrm{b}}$ & $16.9^{\mathrm{b}}$ & $16.7^{\mathrm{b}}$ & 0.4 \\
\hline
\end{tabular}

${ }^{1}$ DMI: dry matter intake, VFA: volatile fatty acids, Ac: acetate, Pr: propionate.

${ }^{2}$ Standard error of the LS means.

$\mathrm{b}, \mathrm{c}, \mathrm{d}$ Means in a row lacking a common superscript differ $(P<0.05)$. 
Table III. Effect of $75 \%$ limited intake on DM digestibility of treated straws.

\begin{tabular}{|c|c|c|c|c|c|c|}
\hline & \multicolumn{2}{|c|}{ Ad-libitum intake } & \multicolumn{2}{|c|}{$75 \%$ limited intake } & \multirow[t]{2}{*}{$\mathrm{SE}^{3}$} & \multirow[t]{2}{*}{$P>\mathrm{F}$} \\
\hline & $\mathrm{n}^{1}$ & $\mathrm{DMD}^{2}(\%)$ & $\mathrm{n}^{1}$ & $\mathrm{DMD}^{2}(\%)$ & & \\
\hline Control & 6 & 53.6 & 6 & 53.7 & 0.88 & 0.94 \\
\hline $\mathrm{NH}_{3}$ & 8 & 56.3 & 8 & 58.5 & 0.74 & 0.04 \\
\hline $\mathrm{NH}_{3}+\mathrm{H}_{2} \mathrm{O}$ & 5 & 59.0 & 5 & 61.3 & 0.97 & 0.095 \\
\hline $\mathrm{NH}_{3}+\mathrm{H}_{2} \mathrm{O}_{2}$ & 6 & 59.1 & 6 & 59.7 & 0.88 & 0.63 \\
\hline Average & 25 & 56.9 & 25 & 58.2 & 0.43 & 0.04 \\
\hline
\end{tabular}

\footnotetext{
${ }_{1}^{1}$ Number of observations (animals who went through the two intake levels).

${ }^{2}$ Dry matter digestibility.
}

${ }^{3}$ Standard error of the LS means.

The effect of $\mathrm{H}_{2} \mathrm{O}_{2}$ was always numerically apparent but not significant. The treatment procedure may have been the reason for that: $\mathrm{NH}_{3}$, which was supposed to raise the $\mathrm{pH}$ for an optimal action of $\mathrm{H}_{2} \mathrm{O}_{2}$, was introduced after $\mathrm{H}_{2} \mathrm{O}_{2}$.

\section{CONCLUSION}

Comparing our results with those of other studies using alkaline hydrogen peroxide, we can conclude that anhydrous ammonia cannot totally replace sodium hydroxide in providing alkalinity for hydrogen peroxide.

\section{REFERENCES}

[1] Association of Official Analytical Chemists, Official Methods of Analysis (15th ed.), Arlington, VA, 1990.

[2] Chestnut A.B., Berger L.L., Fahey G.C. Jr., Effects of ammoniation of tall fescue on phenolic composition, feed intake, site and extent of nutrient digestion and ruminal dilution rates of steers, J. Anim. Sci. 64 (1987) 842-854.

[3] Feist W.C., Baker A.J., Tarkow H., Alkali requirements for improving the digestibility of hardwoods by rumen microorganisms, J. Anim. Sci. 30 (1970) 832-835

[4] Gould J.M., Alkaline peroxide treatment of nonwoody lignocellulosics, U.S. Dep. Agric. Pat. 4649 113, Washington D.C., 1987.
[5] Hach C.C., Bryton S.V., Kopelove A.B., A powerful Kjeldahl nitrogen method using peroxysulfuric acid, J. Agric. Food Chem. 33 (1985) 1117-1123.

[6] Horton G.M.J., Composition and digestibility of cell wall components in cereal straws afte treatment with anhydrous ammonia, Can. J. Anim. Sci. 61 (1981) 1059-1067.

[7] Kerley M.S., Fahey G.C. Jr., Berger L.L. Merchen N.R., Gould J.M., Effect of alkaline hydrogen peroxide treatment of wheat straw on site and extent of digestion in sheep, J. Anim. Sci. 63 (1986) 868-878.

[8] Kernan J.A., Crowle W.L., Spurr D.T. Coxworth E.C., Straw quality of cereal cultivars before and after treatment with anhydrous ammonia, Can. J. Anim. Sci. 59 (1979) 511-517.

[9] Lines L.W., Koch M.E., Weiss W.P., Effect of ammoniation on the chemical composition of alfalfa hay baled with varying concentrations of moisture, J. Dairy Sci. 79 (1996) 2000-2004.

[10] Llamas-Lamas G., Combs D.K., Effects of environmental temperature and ammoniation on utilization of straw by sheep, J. Anim. Sci. 68 (1990) 1719-1725.

[11] Males J.R., Gaskins C.T., Growth, nitrogen retention, dry matter digestibility and ruminal characteristics associated with ammoniated wheat straw diets, J. Anim. Sci. 55 (1982) 505-515.

[12] Mawuenyegah P.O., Warly L., Harumoto T., Fujihara T., Effect of ammoniation or protein supplementation of barley straw on digestion and purine derivative excretion in sheep, Anim. Sci. 64 (1997) 433-439.

[13] National Academy Press, Nutrient Requirements of Sheep (6th ed.), Washington D.C., 1985.

[14] Van Soest P.J., Development of a comprehensive system of feed analysis and its application to forages, J. Anim. Sci. 26 (1967) 119-128. 